\title{
Growth and Yield of Sweetcorn (Zea mays L. var. Macho F1) as Influenced by Different Combination of Organic and Inorganic Fertilizers
}

Enrique Biñas Jr. ${ }^{1}$ and Ulysses Cagasan ${ }^{2 *}$

\section{ABSTRACT}

Organic manures are eco-friendly alternatives to inorganic fertilizers. However, a large volume of organic inputs is needed to meet the nutritional requirements of crops. Hence, there is a need to combine them with inorganic fertilizers to attain better crop yield. This study was conducted to evaluate the effects of the combined application of organic and inorganic fertilizers on the growth and yield performance of sweetcorn and on the profitability of sweetcorn production. The treatments were as follows: $T_{0}$. Control (without fertilizer applied), $T_{1}$ - Inorganic fertilizer at $90-60-60 \mathrm{~kg} \mathrm{ha}^{-1}$ $\left(\mathrm{N}, \mathrm{P}_{2} \mathrm{O}_{5}, \mathrm{~K}_{2} \mathrm{O}\right), \mathrm{T}_{2}-5 \mathrm{t} \mathrm{ha} \mathrm{a}^{-1}$ of vermicompost $+45-30-30 \mathrm{~kg} \mathrm{ha}^{-1} \mathrm{~N}, \mathrm{P}_{2} \mathrm{O}_{5}, \mathrm{~K}_{2} \mathrm{O}, \mathrm{T}_{3}-5$ $\mathrm{t}$ ha ${ }^{-1}$ of poultry manure $+45-30-30 \mathrm{~kg} \mathrm{ha}^{-1} \mathrm{~N}, \mathrm{P}_{2} \mathrm{O}_{5}, \mathrm{~K}_{2} \mathrm{O}, \mathrm{T}_{4^{-}} 5 \mathrm{t} \mathrm{ha}^{-1}$ of cow manure + 45-30-30 kg ha-1 $\mathrm{N}, \mathrm{P}_{2} \mathrm{O}_{5}, \mathrm{~K}_{2} \mathrm{O}, \mathrm{T}_{5}-5 \mathrm{t} \mathrm{ha}^{-1}$ of goat manure + 45-30-30 $\mathrm{kg} \mathrm{ha}^{-1} \mathrm{~N}, \mathrm{P}_{2} \mathrm{O}_{5}, \mathrm{~K}_{2} \mathrm{O}, \mathrm{T}_{6} 5 \mathrm{t} \mathrm{ha}^{-1}$ of mudpress $+45-30-30 \mathrm{~kg} \mathrm{ha}^{-1} \mathrm{~N}, \mathrm{P}_{2} \mathrm{O}_{5}, \mathrm{~K}_{2} \mathrm{O}, \mathrm{T}_{7}$. Foliar spray (Fermented Golden Snail) +45-30-30 kg ha-1 $\mathrm{N}, \mathrm{P}_{2} \mathrm{O}_{5}, \mathrm{~K}_{2} \mathrm{O}$. The experiment was laid out in RCBD with 3 replications. Results showed that sweetcorn plants applied with organic + inorganic fertilizers regardless of source had comparable growth and yield performance to plants applied with pure inorganic fertilizers. The highest net income of PhP62,086.00 hawas obtained from plants applied with combined goat manure and inorganic fertilizers. This suggests that in sweetcorn production, it is feasible to reduce the use of inorganic fertilizers by combining them with organic fertilizers.

Keywords: combined fertilizer application, inorganic fertilizer, organic manures, sweetcorn, yield performance, profitability

${ }^{1}$ Cavite State University, Indang, Cavite, Philippines

${ }^{2}$ Visayas State University, Department of Agronomy, Visca, Baybay City, Leyte, Philippines 


\section{INTRODUCTION}

Corn (Zea mays L.) is the second most important cereal crop next to rice. Because of its versatility, it is grown not only for human and animal consumption, but also as raw material for different food and industrial products (Sailer 2012). Hence, it undergoes intensive crop cultivation. Under intensive crop cultivation, one of the management practices is the application of fertilizers. Inorganic fertilizers are very expensive nowadays. They also have a tendency to pollute the environment and decrease production efficiency (Fageria et al 2007). Organic fertilizers, on the other hand, such as animal manure and crop residues can be used as eco-friendly alternatives to inorganic fertilizers (Sharma and Mittra 1991).

However, recent studies revealed that the application of organic inputs alone cannot meet the nutritional requirements of the crop, so there is a need to integrate these with inorganic fertilizers to achieve better crop yields. The supply of nutrients from organic materials can be complemented by enriching them with inorganic nutrients that will be readily released and used by the crop to compensate for the slow release of organic nutrients. Hence, the use of different organic fertilizers is recommended to minimize the negative impacts of inorganic fertilizers on nature, human health, wildlife, and water sources. A balanced fertilization strategy that combines the use of inorganic and organic or bio-fertilizers must be applied and evaluated (Chen 2006). The judicious use of organic and inorganic nutrient sources is important to decrease dependence on solely inorganic fertilizers. This will also lead to sustainably high crop production due to minimal nutrient loss to the environment and optimum nutrient use (Akhtar et al 2011).

Several studies on the effects of fertilizer application on the yield performance and profitability of corn have already been conducted (Elisan 2015; Motavalli et al 1994). However, most of the published studies focused either on organic or inorganic inputs alone. This study was conducted to determine the effects of the combined application of organic and inorganic fertilizers on the growth and yield performance of sweetcorn and on the profitability of sweetcorn production. Results may be used as basis for making recommendations on the kind and level of organic inputs that can be used to reduce the application of inorganic fertilizers in sweetcorn production.

\section{MATERIALS AND METHODS}

The study was conducted in the experimental site of the Department of Agronomy, VSU, Visca, Baybay City, Leyte. An experimental area of $857.5 \mathrm{~m}^{2}$ was plowed and harrowed twice at weekly intervals to pulverize the soil. 


\section{Growth and Yield of Sweetcorn (Zea mays L. var. Macho F1)}

This was done to incorporate the weeds in the soil and provide good soil condition for seed germination. Furrows were made at a distance of $0.75 \mathrm{~m}$ between rows after the second harrowing.

\section{Experimental Design and Treatments}

This study had eight (8) treatments: $\mathrm{T}_{0}$ - Control (without fertilizer applied), $\mathrm{T}_{1}$ - Inorganic fertilizer at $90-60-60 \mathrm{~kg} \mathrm{ha}^{-1} \mathrm{~N}, \mathrm{P}_{2} \mathrm{O}_{5}, \mathrm{~K}_{2} \mathrm{O}, \mathrm{T}_{2}-5 \mathrm{t}$ ha-1 of vermicompost $+45-30-30 \mathrm{~kg} \mathrm{ha}^{-1} \mathrm{~N}, \mathrm{P}_{2} \mathrm{O}_{5}, \mathrm{~K}_{2} \mathrm{O}, \mathrm{T}_{3}-5 \mathrm{tha}^{-1}$ of poultry manure + 45-30-30 kg ha-1 $\mathrm{N}, \mathrm{P}_{2} \mathrm{O}_{5}, \mathrm{~K}_{2} \mathrm{O}, \mathrm{T}_{4}-5 \mathrm{tha}^{-1}$ of cow manure +45-30-30 kg ha-1 $\mathrm{N}$, $\mathrm{P}_{2} \mathrm{O}_{5}, \mathrm{~K}_{2} \mathrm{O}, \mathrm{T}_{5}-5 \mathrm{t} \mathrm{ha}^{-1}$ of goat manure $+45-30-30 \mathrm{~kg} \mathrm{ha}^{-1} \mathrm{~N}, \mathrm{P}_{2} \mathrm{O}_{5}, \mathrm{~K}_{2} \mathrm{O}, \mathrm{T}_{6}-5$ tha of mudpress $+45-30-30 \mathrm{~kg} \mathrm{ha}^{-1} \mathrm{~N}, \mathrm{P}_{2} \mathrm{O}_{5}, \mathrm{~K}_{2} \mathrm{O}$, and $\mathrm{T}_{7}-$ Foliar spray (Fermented Golden Snail) + 45-30-30 kg ha-1 N, $\mathrm{P}_{2} \mathrm{O}_{5}, \mathrm{~K}_{2} \mathrm{O}$. These were laid out in Randomized Complete Block Design (RCBD) with three replications. Each replication was divided into eight (8) plots measuring $5 \mathrm{~m} \times 4.5 \mathrm{~m}$. An alleyway of $1 \mathrm{~m}$ was provided between replications and between treatment plots to facilitate farm operations and data gathering.

\section{Soil Chemical Properties}

Ten (10) soil sub-samples were randomly collected from the experimental area at 0-20 $\mathrm{cm}$ depth from the soil surface before the conduct of the experiment. These were composited, air-dried, pulverized, and sieved using a $2.0 \mathrm{~mm}$ wire mesh. These were submitted to the Central Analytical Service Laboratory (CASL), Philippine Root Crop Research Center (PhilRootcrops), VSU, Visca, Baybay City, Leyte for the determination of soil $\mathrm{pH}$, organic matter (\%) (Modified Walkley Black Method, PCARR 1980), total N (\%) (Modified Kjedahl Method, PCARR 1980), available phosphorous (Bray No. 2 Method, Jackson 1958), and exchangeable potassium content (Ammonium Acetate Method, PCARR 1980). After harvest, soil samples were gathered for final analysis. Samples were collected per treatment plot at 0-20 cm depth from the surface and composited for the determination of the same soil parameters mentioned above.

\section{Cultural Management Practices}

The organic fertilizers were applied uniformly in the furrows and were incorporated into the soil in each treatment plot two weeks before planting at a rate of $5 \mathrm{t} \mathrm{ha}^{-1}$ for treatments $2,3,4,5$, and 6 . The inorganic fertilizers were applied in the furrows. Complete fertilizer (14-14-14) was drilled 10 days after planting (DAP) at a rate of $90-60-60 \mathrm{~kg} \mathrm{ha}^{-1} \mathrm{~N}, \mathrm{P}_{2} \mathrm{O}_{5}, \mathrm{~K}_{2} \mathrm{O}$ for treatment 1 and $45-30-30 \mathrm{~kg} \mathrm{ha}^{-1} \mathrm{~N}, \mathrm{P}_{2} \mathrm{O}_{5}, \mathrm{~K}_{2} \mathrm{O}$ for treatments $2,3,4,5,6,7$. Urea (46-0-0) was side dressed 30 DAP. The fermented golden snail was applied as foliar spray in treatment 7 , diluted at a ratio of 3 tablespoons to 1 
liter of water and sprayed to plants at weekly intervals. This was done at 7 , $14,21,28$, and 35 DAP.

Two weeks after basal application of organic fertilizer, seeds were directly planted at a rate of 1 seed hill $^{-1}$ to have a desired plant population of 53,333 plants ha ${ }^{-1}$ at a distance of $0.75 \mathrm{~m}$ between rows and $0.25 \mathrm{~m}$ between hills. Seeds were sown on seed trays for replanting of missing hills. Replanting was done 7 DAP. Off-baring was done 15 DAP using a carabao drawn implement to turn the soil away from the base of the plants for better soil aeration and control of weeds. Hilling up was done 30 DAP to cover the side-dressed fertilizer on the second application for better anchorage and stability and to minimize the occurrence of weeds. Hand-weeding was done to control regrowth of weeds within the experimental area after hilling up but the weeds in the surrounding area was maintained to conserve the population of the insect pests' natural enemies.

Insect pests and disease infestation were controlled by the application of botanical pesticide derived from tobacco and powder soap at weekly intervals from V3 (third leaf formation) until VT (tasseling). Daily monitoring of insect pests and diseases was done to assess damage. Marigold flower (Calendula officinalis) was also planted along the sides of the experimental area at a distance of 0.5 meter from the border plants at the sides and alleyways to serve as insect repellant. Sweetcorn was harvested at boiling stage or the green cob stage when it reached its R3 stage (milking). Ten (10) sample plants per treatment were used for gathering data on agronomic characteristics, yield and yield components, and harvest index. These were taken within the harvestable area $\left(13.50 \mathrm{~m}^{2}\right)$.

\section{Data Gathered}

For agronomic characteristics, the following parameters were gathered: number of days from planting to emergence, number of days from planting to tasseling, number of days from planting to silking, number of days from planting to boiling stage, plant height $(\mathrm{cm})$ at maturity, and fresh stover yield $\left(\right.$ tha $\left.^{-1}\right)$. For yield and yield components, the following data were gathered: number of ears plant ${ }^{-1}$, ear length $(\mathrm{cm})$, ear diameter $(\mathrm{cm})$, weight of marketable ears $\left(\mathrm{t} \mathrm{ha}^{-1}\right)$, and total ear yield $\left(\mathrm{t} \mathrm{ha}^{-1}\right)$. Other parameters gathered were the following: harvest index, soil chemical properties, and production cost.

\section{Statistical Tool}

Data were analyzed using the Statistical Tool for Agricultural Research (STAR). Comparison of treatment means was done using the Tukey's or Honestly Significant Difference (HSD) test. 


\section{RESULTS AND DISCUSSION}

\section{Soil Chemical Properties}

Soil test results are presented in Table 1. Initial results revealed that the experimental area had strongly acidic soil (5.51) with adequate organic matter content $(4.00 \%)$, medium total nitrogen $(0.20 \%)$, high potassium $\left(0.84 \mathrm{me}^{100 \mathrm{~g}^{-1}}\right)$, but low phosphorous $\left(6.955 \mathrm{mgkg}^{-1}\right)$ content based on the indices on soil nutrient availability by Landon (1991).

After harvesting the crop, results of the soil analyses indicated that the treatments did not affect soil nutrients except $\mathrm{pH}$ and available $\mathrm{P}\left(\mathrm{mgkg}^{-1}\right)$. Highest $\mathrm{pH}$ value (6.27) was recorded in plots applied with combined poultry manure and inorganic fertilizers $\left(T_{3}\right)$, comparable to plots not applied with any fertilizer $\left(T_{0}\right)$, cow dung and inorganic fertilizers $\left(T_{4}\right)$, goat manure and inorganic fertilizers $\left(T_{5}\right)$, and fermented golden snail and inorganic fertilizers $\left(T_{7}\right)$. This could be attributed to the amount of organic matter content from the organic fertilizer applied to the soil, which in effect, increased the $\mathrm{pH}$ value to slightly acidic. On the other hand, the lowest $\mathrm{pH}$ value (5.56) was recorded in plots applied with pure inorganic fertilizers $\left(T_{1}\right)$. This could be attributed to the high soil acidity (lower $\mathrm{pH}$ value) from urea hydrolysis and the ammonium content of inorganic fertilizer. According to Jenkins (2015), fertilizer containing ammonium acidifies the soil. Ammonium nitrogen from fertilizer is readily converted to nitrate and hydrogen ions by bacteria in the soil. This contributes different amounts of hydrogen ions to the soil, depending on the fertilizer. He further added that inorganic fertilizer can easily leach its nitrate and sulfate which causes acidification.

The relative increase in $P$ after harvest could be attributed to the mineralization of organic fertilizers. Nutrient analyses of different manures (Table 2 ) revealed that poultry manure had the highest P content $(2.226 \%)$, thus plots applied with poultry manure and inorganic fertilizers $\left(T_{3}\right)$ obtained the highest $\mathrm{P}$ content after harvest relative to the plots applied with pure inorganic fertilizers $\left(T_{1}\right)$, comparable to those with vermicompost $\left(T_{2}\right)$, cow dung $\left(T_{4}\right)$, and mudpress (T6) combined with inorganic fertilizers. 
Biñas \& Cagasan

Table 1. Soil analysis before planting and after harvesting as affected by different levels of organic and inorganic fertilizers

\begin{tabular}{|c|c|c|c|c|c|}
\hline Treatment & $\begin{array}{c}\text { pH } \\
(1: 2.5)\end{array}$ & $\begin{array}{l}\mathrm{OM} \\
(\%)\end{array}$ & $\begin{array}{c}\text { Total N } \\
(\%)\end{array}$ & $\begin{array}{c}\text { Available P } \\
\left(\mathrm{mg} \mathrm{kg}^{-1}\right)\end{array}$ & $\begin{array}{l}\text { Exchangeable } \\
\mathrm{K}\left(\mathrm{cmol} \mathrm{kg}^{-1}\right)\end{array}$ \\
\hline \multicolumn{6}{|c|}{ A. Initial (before planting) } \\
\hline & 5.51 & 4.0 & 0.20 & 6.95 & 0.84 \\
\hline \multicolumn{6}{|c|}{ B. Final (after harvest) } \\
\hline $\mathrm{T}_{0}$ & $6.08 \mathrm{ab}$ & 2.20 & 0.11 & $8.11 b$ & 0.86 \\
\hline $\mathrm{T}_{1}$ & $5.57 \mathrm{c}$ & 2.20 & 0.11 & $33.56 a$ & 0.75 \\
\hline $\mathrm{T}_{2}$ & $5.80 \mathrm{bc}$ & 2.20 & 0.11 & $15.81 a b$ & 0.59 \\
\hline $\mathrm{T}_{3}$ & $6.27 a$ & 2.40 & 0.12 & $31.05 \mathrm{a}$ & 0.96 \\
\hline $\mathrm{T}_{4}$ & $5.98 \mathrm{ab}$ & 2.20 & 0.11 & $13.58 \mathrm{ab}$ & 0.69 \\
\hline $\mathrm{T}_{5}$ & $6.01 \mathrm{ab}$ & 2.40 & 0.12 & $9.30 \mathrm{~b}$ & 0.97 \\
\hline $\mathrm{T}_{6}$ & $5.84 b c$ & 2.00 & 0.10 & 16.63ab & 0.61 \\
\hline $\mathrm{T}_{7}$ & $6.01 \mathrm{ab}$ & 2.00 & 0.10 & $7.25 b$ & 0.68 \\
\hline Mean & 5.94 & 2.20 & 0.11 & 16.92 & 0.76 \\
\hline CV (\%) & 2.04 & 18.69 & 15.78 & 23.30 & 22.49 \\
\hline
\end{tabular}

Treatments within a column with the same and without letter designations are not significantly different at $\mathrm{p} \leq 0.05$.

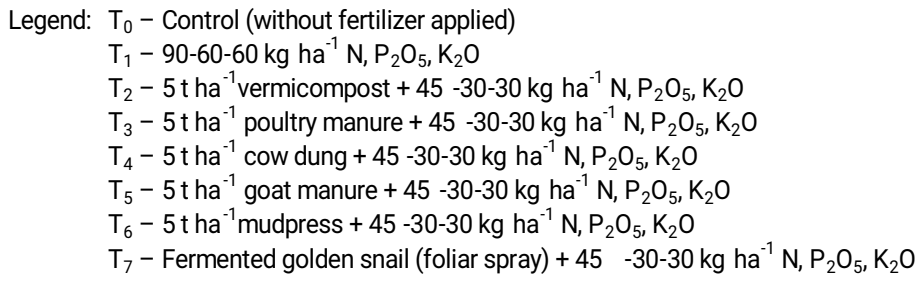

On the other hand, the significant decrease in organic matter after harvest despite adding organic materials can be attributed to the presence of decaying organisms, or an increased rate of decay as a result of changes in natural anthropogenic conditions of the soil leading to the decline in organic matter (Ojeniyi 2002).

\section{Chemical Properties of Organic Fertilizers}

The chemical properties of organic fertilizers are presented in Table 2. Different organic fertilizers contain adequate amounts of nutrients. These contributed to the significantly greater number, size, length, and marketable ears of sweetcorn compared with those not applied with any of these organic fertilizers. Thus, in general, there was improvement in the growth and yield parameters of sweetcorn. 
Growth and Yield of Sweetcorn (Zea mays L. var. Macho F1)

Table 2. Chemical properties of different organic fertilizers

\begin{tabular}{lccccc}
\hline & $\mathbf{p H}$ & $\mathbf{O C}$ & \multicolumn{3}{c}{ Total } \\
\cline { 5 - 6 } & $(\mathbf{1 : 2 . 5 )}$ & $\mathbf{( \% )}$ & $\begin{array}{c}\mathbf{N} \\
(\mathbf{\%})\end{array}$ & $\begin{array}{c}\mathbf{P} \\
\left(\mathbf{m g ~ k g ~}^{-1}\right)\end{array}$ & $\begin{array}{c}\mathbf{K} \\
\left(\mathbf{c m o l ~ k g ~}^{-1}\right)\end{array}$ \\
\hline Vermicompost & 6.20 & 2.34 & 1.89 & 0.54 & 0.17 \\
Poultry dung & 8.73 & 2.17 & 3.04 & 2.22 & 3.51 \\
Cow dung & 8.49 & 2.54 & 2.01 & 0.44 & 1.36 \\
Goat manure & 8.61 & 2.79 & 2.44 & 0.30 & 2.20 \\
Mudpress & 6.66 & 2.92 & 2.27 & 0.96 & 0.22 \\
FGS & 6.50 & nd & 0.25 & trace & 0.13 \\
\hline
\end{tabular}

nd-no data

\section{Agronomic Characteristics of Sweetcorn}

The agronomic characteristics of sweetcorn applied with different organic materials combined with inorganic fertilizer are presented in Figure 1. Statistical analyses revealed that all agronomic characteristics of sweetcorn, except the stover yield $\left(\right.$ tha $\left.^{-1}\right)$, were significantly affected by the treatments as shown in Figure 1c. All plants applied with organic and inorganic fertilizers regardless of nutrient sources $\left(T_{1}, T_{2}, T_{3}, T_{4}, T_{5}, T_{6}\right.$ and $\left.T_{7}\right)$ reached the boiling stage earlier compared to those plants not applied with any fertilizer $\left(T_{0}\right)$. This could be attributed to the early tasseling and silking of fertilized plants (Figure 1a). Chen (2006) found that unfertilized corn developed slower compared to fertilized plants. This result confirmed the findings of Sailer (2012) that corn in less fertile soil had delayed boiling stage and maturity. Chen (2006) also reported that the application of combined organic manure and inorganic fertilizers enhances the growth and development of corn, thus the crop matured earlier.

Plants applied with pure inorganic fertilizer and a combination of organic and inorganic fertilizers regardless of source were significantly taller than those $\left(T_{0}\right)$ not applied with any fertilizer (Figure $1 \mathrm{~b}$ ). This result can be attributed to the adequate amount of nutrients from the fertilizers applied. The nutrients were already released and absorbed by the plants, causing the internode of the sweetcorn to elongate. As the internodes elongate, the stalks increase their length, hence increasing the plant height. This further conforms to the findings of Elisan (2015) that the application of combined organic and inorganic fertilizers significantly increased the height $(\mathrm{cm})$ of glutinous corn. 
(a)

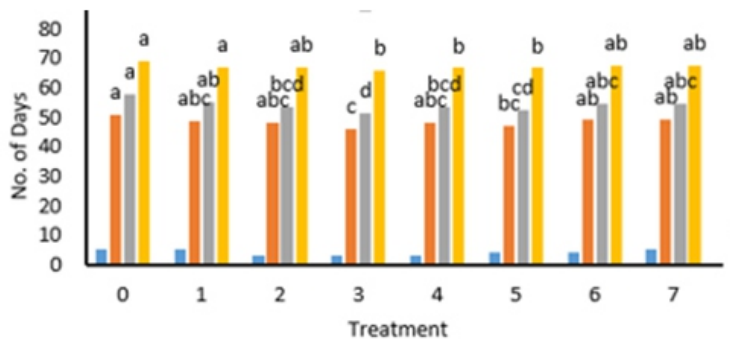

= From Planting to Emergence $=$ From Planting to Tasseling
$=$ From Planting to Silking $\quad$ EF From Planting to Boiling Stage
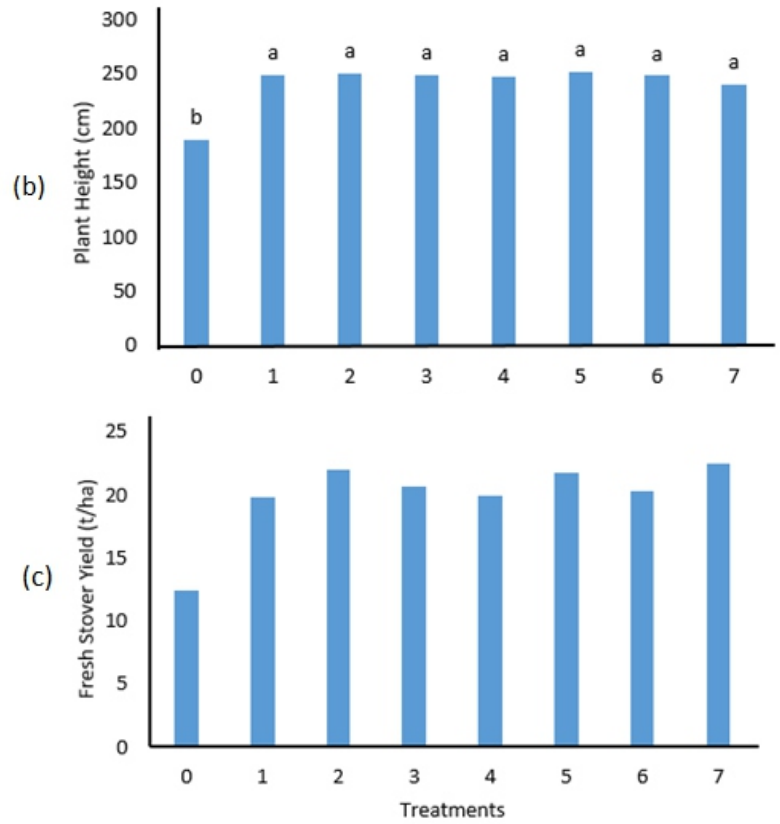

Treatment means with the same and without letter designations are not significantly different at 0.05 HSD.

Legend: $\quad \mathrm{T}_{0}$ - Control (without fertilizer applied)

$\mathrm{T}_{1}-90-60-60 \mathrm{~kg} \mathrm{ha}^{-1} \mathrm{~N}, \mathrm{P}_{2} \mathrm{O}_{5}, \mathrm{~K}_{2} \mathrm{O}$

$\mathrm{T}_{2}-5$ t ha-1 vermicompost $+45-30-30 \mathrm{~kg} \mathrm{ha}^{-1} \mathrm{~N}, \mathrm{P}_{2} \mathrm{O}_{5}, \mathrm{~K}_{2} \mathrm{O}$

$\mathrm{T}_{3}-5 \mathrm{t} \mathrm{ha}^{-1}$ poultry manure $+45-30-30 \mathrm{~kg} \mathrm{ha}^{-1} \mathrm{~N}, \mathrm{P}_{2} \mathrm{O}_{5}, \mathrm{~K}_{2} \mathrm{O}$

$\mathrm{T}_{4}-5 \mathrm{t} \mathrm{ha}^{-1}$ cow dung + 45-30-30 kg ha- $\mathrm{N}^{-1} \mathrm{P}_{2} \mathrm{O}_{5}, \mathrm{~K}_{2} \mathrm{O}$

$\mathrm{T}_{5}-5 \mathrm{t} \mathrm{ha}^{-1}$ goat manure $+45-30-30 \mathrm{~kg} \mathrm{ha}^{-1} \mathrm{~N}, \mathrm{P}_{2} \mathrm{O}_{5}, \mathrm{~K}_{2} \mathrm{O}$

$\mathrm{T}_{6}-5 \mathrm{t} \mathrm{ha}^{-1}$ mudpress $+45-30-30 \mathrm{~kg} \mathrm{ha}^{-1} \mathrm{~N}, \mathrm{P}_{2} \mathrm{O}_{5}, \mathrm{~K}_{2} \mathrm{O}$

$\mathrm{T}_{7}$ - Fermented golden snail (foliar spray) +45-30-30 kg ha-1 $\mathrm{N}, \mathrm{P}_{2} \mathrm{O}_{5}, \mathrm{~K}_{2} \mathrm{O}$

Figure 1. Agronomic characteristics of sweetcorn: (a) number of days from planting to emergence, tasseling, silking and boiling stage; (b) plant height (cm); (c) fresh stover yield (t/ha) applied with different organic materials combined with inorganic fertilizers 


\section{Yield and Yield Components of Sweetcorn}

The yield and yield characteristics of sweetcorn applied with different organic materials combined with inorganic fertilizers are presented in Figure 2. Results indicate that plants applied with combined poultry manure and inorganic fertilizers $\left(T_{3}\right)$ had significantly more ears compared to those applied with combined cow dung and inorganic fertilizers $\left(\mathrm{T}_{4}\right)$. Expectedly, unfertilized plants obtained the least ears due to insufficient nutrients for ear development (Figure 2a). Different applications of various organic materials combined with inorganic fertilizers produced sweetcorn which had significantly longer and larger ears (cm) (Figure 2b), had more marketable ears, heavier marketable ears (kgha ${ }^{-1}$ ) (Table 3), and total ear yield ( $\mathrm{t} \mathrm{ha}{ }^{-1}$ ) than the untreated control plants (Figure $2 \mathrm{c}$ ). The significantly longer and bigger ears contributed to the significant weight of marketable ears of fertilized plants regardless of nutrient sources. Thus, the fertilized plants significantly obtained higher total ear yield ( $\mathrm{t} \mathrm{ha}{ }^{-1}$ ) compared to the untreated control $\left(\mathrm{T}_{0}\right)$. This could be attributed to the adequate amount of nutrients from the different organic fertilizers (Table 2) and inorganic fertilizers applied. Burr (1979) reported that sweetcorn required the minimum rate of $90-60-60 \mathrm{~kg} \mathrm{ha}^{-1} \mathrm{~N}, \mathrm{P}_{2} \mathrm{O}_{5}, \mathrm{~K}_{2} \mathrm{O}$. On the other hand, sweetcorn not applied with fertilizer had the lowest yield. The result implies the benefits of the combination of organic and inorganic fertilizers on the significant yield increase in green cob of sweetcorn. Ojeniyi (2002) also reported that the combination of organic and inorganic fertilizers can significantly improve the yield of corn. Moreover, the application of $50 \%$ of the recommended rate of inorganic fertilizer combined with 5 tha $^{-1}$ organic fertilizer could have provided readily available plant nutrients which improved corn yield and productivity. Likewise, Motavalli et al (1994) found that the combined application of organic and inorganic fertilizers to the soil improved corn yield and its quality in terms of flavor and storability.

\section{Profitability}

The profitability of sweetcorn production $\mathrm{ha}^{-1}$ applied with different organic materials combined with inorganic fertilizers is presented in Table 5. All fertilized plants had higher gross income compared to plants without fertilizer. Results show that the higher marketable ear yield greatly contributed to the increase in gross income.

The highest net income of PhP 62,086.00 ha ${ }^{-1}$ was obtained from plants applied with combined goat manure and inorganic fertilizers $\left(T_{5}\right)$, followed by plants applied with combined cow dung and inorganic fertilizers $\left(T_{4}\right)(P h P$ $\left.52,786.00 \mathrm{ha}^{-1}\right)$, and plants applied with pure inorganic fertilizer $\left(\mathrm{T}_{1}\right)$ (PhP47,594.00 ha $^{-1}$ ) due to their high marketable ear yield and slightly lower production cost. 
(a)

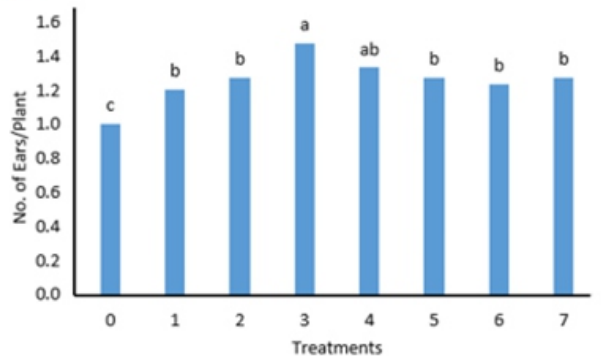

(c)

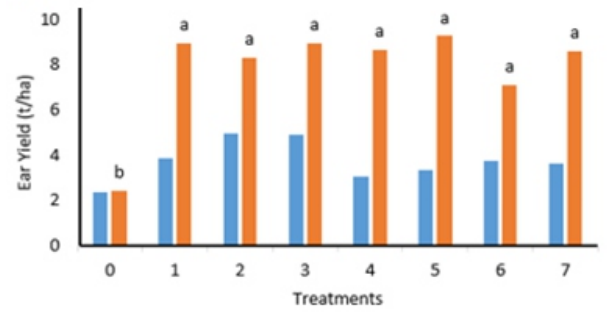

- Non-marketable Ear Yield = Total Ear Yield (b)

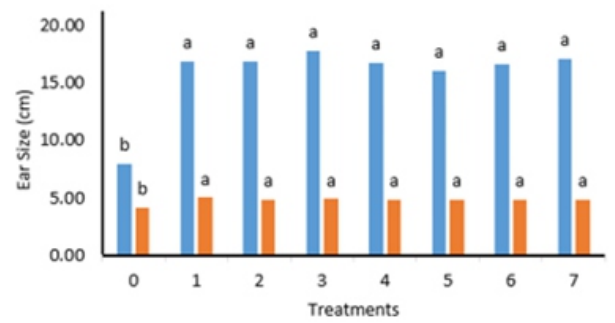

= Ear Length $=$ Ear Diameter

(d)

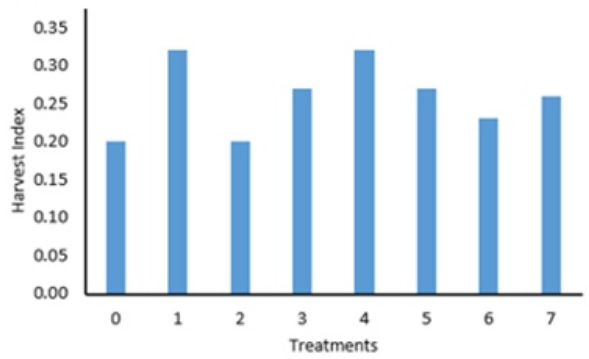

Treatment means with the same and without letter designations are not significantly different at 0.05 HSD.

Legend: $\quad \mathrm{T}_{0}-$ Control (without fertilizer applied)

$\mathrm{T}_{1}-90-60-60 \mathrm{~kg} \mathrm{ha}^{-1} \mathrm{~N}, \mathrm{P}_{2} \mathrm{O}_{5}, \mathrm{~K}_{2} \mathrm{O}$

$\mathrm{T}_{2}-5 \mathrm{t}$ ha ${ }^{-1}$ vermicompost $+45-30-30 \mathrm{~kg} \mathrm{ha}^{-1} \mathrm{~N}, \mathrm{P}_{2} \mathrm{O}_{5}, \mathrm{~K}_{2} \mathrm{O}$

$\mathrm{T}_{3}-5 \mathrm{t} \mathrm{ha}^{-1}$ poultry manure $+45-30-30 \mathrm{~kg} \mathrm{ha}^{-1} \mathrm{~N}, \mathrm{P}_{2} \mathrm{O}_{5}, \mathrm{~K}_{2} \mathrm{O}$

$\mathrm{T}_{4}-5 \mathrm{t} \mathrm{ha}^{-1}$ cow dung + 45-30-30 kg ha- $\mathrm{N}^{-1} \mathrm{P}_{2} \mathrm{O}_{5}, \mathrm{~K}_{2} \mathrm{O}$

$\mathrm{T}_{5}-5 \mathrm{t} \mathrm{ha}^{-1}$ goat manure $+45-30-30 \mathrm{~kg} \mathrm{ha}^{-1} \mathrm{~N}, \mathrm{P}_{2} \mathrm{O}_{5}, \mathrm{~K}_{2} \mathrm{O}$

$\mathrm{T}_{6}-5 \mathrm{t} \mathrm{ha}^{-1}$ mudpress $+45-30-30 \mathrm{~kg} \mathrm{ha}^{-1} \mathrm{~N}, \mathrm{P}_{2} \mathrm{O}_{5}, \mathrm{~K}_{2} \mathrm{O}$

$\mathrm{T}_{7}$ - Fermented golden snail (foliar spray) $+45-30-30 \mathrm{~kg} \mathrm{ha}^{-1} \mathrm{~N}, \mathrm{P}_{2} \mathrm{O}_{5}, \mathrm{~K}_{2} \mathrm{O}$

Figure 2. Yield, yield components: (a) number of ears per plant; (b) ear size (cm); (c) ear yield $\left(\mathrm{t} \mathrm{ha}^{-1}\right)$, and (d) harvest index of hybrid sweetcorn applied with different organic materials combined with inorganic fertilizers 
Growth and Yield of Sweetcorn (Zea mays L. var. Macho F1)

Table 3. Cost and return analysis of hybrid sweetcorn production ha" applied with different organic materials combined with inorganic fertilizers

\begin{tabular}{ccrrr}
\hline Treatment & $\begin{array}{c}\text { Marketable } \\
\text { Ear Yield } \\
\left(\mathrm{t} \mathrm{ha}^{-}{ }^{-}\right)\end{array}$ & $\begin{array}{c}\text { Gross } \\
\text { Income } \\
\left(\text { (PhP ha }^{-1}\right)\end{array}$ & $\begin{array}{c}\text { Production } \\
\text { Cost } \\
\left(\text { PhP ha }^{-1}\right)\end{array}$ & $\begin{array}{c}\text { Net Income } \\
\left(\text { PhP ha }^{-1}\right)\end{array}$ \\
\hline $\mathrm{T}_{0}$ & $0.05 \mathrm{~b}$ & $1,250.00$ & $51,620.00$ & $-50,370.00$ \\
$\mathrm{~T}_{1}$ & $5.07 \mathrm{a}$ & $126,750.00$ & $79,156.00$ & $47,594.00$ \\
$\mathrm{~T}_{2}$ & $3.33 \mathrm{a}$ & $83,250.00$ & $117,304.00$ & $-34,054.00$ \\
$\mathrm{~T}_{3}$ & $4.03 \mathrm{a}$ & $100,750.00$ & $87,484.00$ & $13,266.00$ \\
$\mathrm{~T}_{4}$ & $5.55 \mathrm{a}$ & $138,750.50$ & $85,964.00$ & $52,786.00$ \\
$\mathrm{~T}_{5}$ & $5.93 \mathrm{a}$ & $148,250.00$ & $86,164.00$ & $62,086.00$ \\
$\mathrm{~T}_{6}$ & $3.38 \mathrm{a}$ & $84,500.00$ & $84,724.00$ & -224.00 \\
$\mathrm{~T}_{7}$ & $4.95 \mathrm{a}$ & $123,750.00$ & $86,134.00$ & $37,616.00$ \\
\hline
\end{tabular}

Gross income was computed based on the current wholesale/farm gate price of sweetcorn at PhP $25.00 \quad \mathrm{Kl}^{-1}$ in the locality.

Legend: $\mathrm{T}_{0}-$ Control (without fertilizer applied)

$\mathrm{T}_{1}-90-60-60 \mathrm{~kg} \mathrm{ha}^{-1} \mathrm{~N}, \mathrm{P}_{2} \mathrm{O}_{5}, \mathrm{~K}_{2} \mathrm{O}$

$\mathrm{T}_{2}-5 \mathrm{t} \mathrm{ha}^{-1}$ vermicompost $+45-30-30 \mathrm{~kg} \mathrm{ha}^{-1} \mathrm{~N}, \mathrm{P}_{2} \mathrm{O}_{5}, \mathrm{~K}_{2} \mathrm{O}$

$\mathrm{T}_{3}-5 \mathrm{t} \mathrm{ha}^{-1}$ poultry manure $+45-30-30 \mathrm{~kg} \mathrm{ha}^{-1} \mathrm{~N}, \mathrm{P}_{2} \mathrm{O}_{5}, \mathrm{~K}_{2} \mathrm{O}$

$\mathrm{T}_{4}-5 \mathrm{t} \mathrm{ha}^{-1}$ cow dung $+45-30-30 \mathrm{~kg} \mathrm{ha}^{-1} \mathrm{~N}, \mathrm{P}_{2} \mathrm{O}_{5}, \mathrm{~K}_{2} \mathrm{O}$

$\mathrm{T}_{5}-5 \mathrm{t} \mathrm{ha}^{-1}$ goat manure $+45-30-30 \mathrm{~kg} \mathrm{ha}^{-1} \mathrm{~N}, \mathrm{P}_{2} \mathrm{O}_{5}, \mathrm{~K}_{2} \mathrm{O}$

$\mathrm{T}_{6}-5 \mathrm{t} \mathrm{ha}^{-1}$ mudpress $+45-30-30 \mathrm{~kg} \mathrm{ha}^{-1} \mathrm{~N}, \mathrm{P}_{2} \mathrm{O}_{5}, \mathrm{~K}_{2} \mathrm{O}$

$\mathrm{T}_{7}$ - Fermented golden snail (foliar spray) +45-30-30 kg ha-1 $\mathrm{N}, \mathrm{P}_{2} \mathrm{O}_{5}, \mathrm{~K}_{2} \mathrm{O}$

The cost of organic materials differed among treatments. The highest cost was incurred from the combination of vermicompost and inorganic fertilizers $\left(T_{2}\right)$ because of the high price of vermicompost, but since it has low amount of nutrients (Table 2 ) relative to mudpress $\left(T_{6}\right)$, the returns were negative. The combination of goat manure and inorganic fertilizers $\left(T_{5}\right)$ was more profitable and advantageous because goat manure is cheap but it has high amounts of nutrients (Table 2). Thus, this treatment produced the highest yield and net income. 


\section{CONCLUSION}

Results of this study showed that hybrid sweetcorn applied with a combination of inorganic and organic fertilizers regardless of the source had comparable growth and yield performance to plants applied with pure inorganic fertilizers. Thus, in sweetcorn production, it is feasible to partly substitute inorganic fertilizer with locally available organic fertilizer. The combination of goat manure and inorganic fertilizers $\left(T_{5}\right)$ appeared to be the best combination as it gave the highest net income of PhP62,086.00 ha-1.

\section{RECOMMENDATION}

To save on the cost of fertilizer for sweetcorn production, the combined application of inorganic fertilizers and locally available and low-cost organic fertilizer like goat manure or cow dung is recommended. A similar study may be conducted to further evaluate the growth and yield response of sweetcorn to combined fertilizer application under different agro-climatic conditions.

\section{ACKNOWLEDGMENT}

The authors would like to thank the Department of Science and Technology-Accelerated Science and Technology Human Resource Development Program-National Science Consortium (ASTHRDP-NSC) for funding this study.

\section{REFERENCES}

Akhtar M, Naeem A, Akhter J, Bokhari SA \& Ishaque W. 2011. Improvement in nutrient uptake and yield of wheat by combined use of urea and compost. Soil \& Environment, 30: 45-49.

Burr J, Mansour NS, Gardner EH, Mack HJ \& Jackson TL.1979. Sweet corn: eastern Oregon, east of Cascades. Retrieved f rom ht t p : / / oregonstate. ed u / d e p t /hermiston/sites/default/files/sweet_corn_fg62-e2.pdf

Chen JH. 2006. The combined use of chemical and organic fertilizers and/or biofertilizer for crop growth and soil fertility. In International workshop on sustained management of the soil-rhizosphere system for efficient crop production and fertilizer use (Vol. 16, p. 20). Land Development Department Bangkok, Thailand.

Elisan B. 2015. Growth and yield of glutinous corn (Zea mays L.) as influenced by the application of different combinations of organic and inorganic fertilizers. Unpublished Undergraduate Thesis. Capiz 
State University, Pontevedra, Capiz. Pp 79.

Fageria NK. 2007. Green manuring in crop production. Journal of Plant Nutrition 30: 691-719.

Jenkins T. 2015. How do chemical fertilizers affect the soil pH in acid, neutral and slightly alkaline soil? Indian Institute of Soil Science. Retrieved from www.researchgate.net.

Landon JR. 1991. Booker tropical soil manual: A Handbook for Soil Survey and Agricultural Land Evaluation in the Tropics and Subtropics. Longman Scientific and Technical, Essex, New York. 474p.

Motavalli PP, Singh RP \& Aanders MM. 1994. Perception and management of farmyard manure in the semi-arid tropics of India. Agricultural systems. 46: 189-204.

Ojeniyi SO. 2002. Soil management, national resources and environment. Oke-Ado: Adeniran press. pp 24.

PCARRD. 1980. Standard Methods of Analysis for Soil, Plant Tissue, Water and Fertilizer. Los Baños, Laguna. $194 \mathrm{pp}$.

Sailer L. 2012. The Importance of Corn Journal. Industry News. The Field $\mathrm{P}$ o s i t i o $\mathrm{n}$. $\mathrm{R}$ e $\mathrm{t} \mathrm{r}$ i e $\mathrm{v}$ e d $\mathrm{f} \mathrm{O} \mathrm{m}$ http://www.thefieldposition.com/2012/06/the-importance-ofcorn/

Sharma AR and Mittra BN. 1991. Effect of different rates of application of organic and nitrogen fertilizers in a rice-based cropping system. Journal of Agricultural Science (Camb.)1991;117:313-318. 